\title{
Misogynism and the Dynamics of Power: A Radical Feminist Reading of Angela Makholwa's Black Widow Society
}

\author{
Prosper A. NtamboNtambo ${ }^{1 *}$, Pamela Christelle $\mathrm{N}^{1}$ \\ ${ }^{1}$ Ph.D. student, The University of Maroua
}

\author{
*Corresponding Author: Prosper A. NtamboNtambo, Ph.D. student, The University of Maroua, \\ Cameroon
}

\begin{abstract}
Women around the globe and Africa in particular have been subservient to men. They always play a second role and are sometimes considered as the weaker sex. Women suffer three facets of colonization which are, race, class and sexual orientation. This paper unravels the fact that sexual orientation as heterosexuals lead to their oppression and black women in post-apartheid South Africa still live at the margins of the society. They are not fully given a voice, and the space they deserve is most often circumscribed. They are often associated with negative images like poverty, marginalization, sexual assault, depersonalization, amongst others. As a result, women can still be termed as being part of the subaltern group as the access to their rights have not been completely acquired. Read against the backdrop of Radical feminist discourse, this paper argues that the women in Makhlowa's oeuvre have resorted into acts of taboo like, murder, lesbianism, prostitution amongst others in order to redefine a space of their own. Although radical feminists argue that women's oppression will not be eradicated simply by reforming political or economic institutions; rather, feminists must transform the entire gender system. In her text, women not only recognize the destructive patriarchal images of women that permeate their sense of self but also that they create a world other than patriarchy. This crime fiction posits that a woman's place and space in society should be well defined in order not to spur the chaotic and morally barren society that prevails in this text. It also depicts how battered women in order to liberate themselves from the chasms and prism of male domination and suppression, flout all moral conventions in sheer savagery. These women transgress all the social barriers in order to create their space and give meaning to their existence. By transgressing the code prescribed for them, women resist against their oppression by empowering themselves sexually through the expression of free sexualities which is exhibited through prostitution and lesbianism. They also empower themselves by taking away their husband's lives who always impede on their freedom.
\end{abstract}

Keywords: Dynamics, radical feminism, taboo, misogynism and crime fiction.

\section{INTRODUCTION}

From time immemorial, women have been suffering from inequality to men and this has been a considerable concern for many female writers. This culture of subjugating women is worldwide and has successfully been handed down from one generation to another. This is made possible by their ability not to change the way things are, is limited by the absence of values that are themselves transformative. Transformation of values must coincide with and stimulate the undoing of systems of gender-based oppression. Most of the canonical texts of feminists discourse are predominantly written by men and they do so from their own standpoint. These varied ideologies have often, been attributed largely, to the specificity of place and time, which compels women to prefer one brand of feminist movement to another. In the midst of varied definitions of the term feminism by different critics, the definition offered by Joni Lovenduski and Vicky Randall (1993) which states that any ideology, activity and policy "whose goal is to remove discrimination against women and to break down the male domination of society" (19) seems more appropriate for the purpose of this paper. Existing feminist theories such as Marxist, radical, liberal, socialist, anarcha, ecological and psychoanalytical all propound ideologies that address the status of the female in the patriarchal society. However, the theory that best suits the argument being pursued in this paper is radical feminism, although it should be noted that all the theories are intertwined. The aim behind their empowerment is not only to disem power the men but also to make themselves stronger before male dominant figures, which through physical and psychological oppression make women weaker and vulnerable. Zimmermann and 
Rappaport [1996] define empowerment as an active process. Its form is determined by the circumstances and events but its essence is human activity in the direction of change from a passive state to an active one. They further posit that the process brings about an integration of selfacceptance and self-confidence, social and political understanding in decision making and in control over the resources of the environment' (76). Thus women's empowerment does not only make them stronger before the men, but also by attaining these different levels of power, women directly resist patriarchal norms which are instituted by the colonial ideology. When women empower themselves, they strip themselves of colonial and patriarchal principles which are ascribed for them and which some are bound to follow. These ascribed roles constantly tie the women down thus, preventing them from expressing their true identity.

Contending that gender has been constructed in order to ensure women's subordination, radical feminists argue that women's oppression will not be eradicated simply by reforming political or economic institutions; rather, feminists must transform the entire gender system. Shulamith Firestone identified a phenomenon she termed 'sex class'-the condition of women as an oppressed class "so deep to be invisible" (1). In her book The Dialectic of Sex (1970), Firestone articulated her version of the central tenet of radical feminism: "Man's domination of woman is the fundamental form of oppression, one that is so intricately woven into virtually all facets of our lives that it thoroughly pervades our sense of what it is to be a woman or to be a man" (42). Mary Daly (1976), for example, defines radical feminism as a "journey of becoming"(1). In other words, Daly argues that feminism requires that women not only recognise the destructive patriarchal image of woman that permeate their sense of self but also that they create a world other than patriarchy. Radical feminism is therefore a perspective within feminism that calls for a radical reordering of society in which male supremacy is eliminated in all social and economic contexts. Radical feminists seek to abolish patriarchy by challenging the notion of traditional gender roles, opposing the sexual objectification of women, and raising public awareness about such issues as rape and violence against women. Radical feminists locate the root cause of women's oppression in patriarchal gender relations, as opposed to legal systems (as in liberal feminism) or class conflict (as in anarchist, socialist and Marxist feminisms). While some radical feminist propose that the oppression of women is the most fundamental form of oppression, one that cuts across boundaries of all other forms of oppression, others acknowledge the simultaneous and intersecting effect of other independent categories of oppression. These other categories of oppression may include, but are not limited to, oppression based on race, social class, perceived attractiveness, sexual orientation, and ability. Some radical feminists such as Phyllis Chesler, Monique Wittig, Mary Daly, Jill Johnston and Robin Morgan have called upon women to govern women and men alike. They assert that society is a patriarchy in which the class of men are the oppressors of the class of women and because of that, women have systematically been viewed as the 'other' to the male norm. They fervently hold the conviction that; the way to deal with oppression of any kind is to address the underlying causes of it is through revolution of any kind too. Alice Echols and Ellen Willis (1990) argue that, the main difference between radical feminism and other branches is that they didn't concentrate on equalising the distribution of power. Instead, they focused their efforts on completely eliminating patriarchy by transforming the entire structure of society. It is from this basis that we analyse this paper using radical feminism as the female characters in Makhowa's text want to get rid of traditional gender roles through their sexual deviancy, murdering of their husbands and economic independence.

\section{Postmodernists or Social DeViants}

Women's sexualities as history records have transcended the normal heterosexual relationship between a man and a woman. Postmodern works in contrast to other approaches, considers women's sexuality as neither a subversive sexual practice nor an inherently oppressive one. Some women, through lesbianism and prostitution rebel against social constructs as far as women's sexualities are concerned. By so doing, they free themselves from patriarchal and colonial bondage and frame themselves new identities. The freedom they obtain as far as their sexualities are concerned makes them not to live according to a predetermined script and makes them live a sexually happy life. Considering the above statements, women get to attain free sexualities. These free sexualities do not 
only make them to attain self-fulfillment but equally a symbol of their resistance because they go against the description of femininity prescribed by patriarchy and colonialism. From the deviant acts of these women they freely express their sexualities, by refusing to act like automats.

Also, Due to their unusual behaviors, the women in Makholwa's Black Widow Society can be termed "social deviants" by patriarchy because they decide to adopt a deviant sexual life. For Khumalo, Tallulah, Nomhle, Thami and Janine, the sexual liberty they express should not be perceived as deviant sexual attitudes because it is an expression of their empowerment and their resistance vis-àvis the bondage that some men have subjected them to and a way to live a self-fulfilled existence. Women attain self-fulfillment through these sexual taboo acts because at a certain point in some of their lives, even their sexuality which is the only thing that belongs to them is regulated by the society. The above situation is represented in Makholwa's narrative where Tallulah's Husband often imposes the old missionary position when they make love which in turn leads to Tallulah`s dissatisfaction. This instance depicts how Tallulah lives a sad marital sexual life. As she is not the only one in this situation, many other women in her situation go craving for sex when they realize they have not really enjoyed a happy and enticing sexual life with their partners. Thus, the women in this novel are a representation of women who have unfulfilled and unsatisfied sexual lives. Trying to have sex in different positions allegorically represents breaking away with patriarchal norms and trying to achieve self-satisfaction. The sex imagery is used allegorically, women empower themselves through the free sexualities in a bid to attain self-fulfilment and resist against patriarchal norms. From Tallulah's marriage experience, she is always tied down emotionally, financially and sexually by Mphikeleli- her husband who has total control over her life. As far as her sexuality is concerned, she does not really enjoy a happy sexual life because her husband always handles everything on bed and never gives her that audacity to express herself during their sexual intercourses. Tallulah's sexual monotony is revealed when the narrator says:

Sex with Mphikeleli had always seemed quite perfunctory and mechanical; she'd married him when she was twenty years old and barely out of her school tunic so she'd merely gone along with whatever he wanted in the bedroom, which was usually just the boring old missionary position. It was only after he'd left the land of the living that she started experiencing the exciting variation that came with making love to more sexually experienced men. In time she began to understand what she liked, how she liked to be handled in bed, for this was after all the only domain where she could indeed 'be handled'. (Makholwa, 2013:107)

From the above citation, we realize that Tallulah lives a sad marriage life which is not only accompanied by emotionally frustrations through her husband's constant beatings but equally by sexual frustrations due to the dissatisfaction she feels during their love making. From this instance, the death of Tallulah's husband is equally seen as a blessing, because his death does not only symbolize her individual freedom, but also her sexual empowerment. This is duly because once he dies; she lives the sexual life she always desired as she now knows what she wants and what she does not want while in bed with a man. From this instance, it is also revealed to us that it is the only domain that she can be handled. This statement reveals how powerful Tallulah has become in all the spheres of life. Sexually, Tallulah has gained a lot of experience, she knows what pleases her and she also knows which sexual partner can suit her thereby making her feel younger. This situation is exposed when she begins to choose more experienced men who can satisfy her libido. Tallulah's sexual freedom is revealed when the narrator says: "When she discovered how liberating it could be to allow that domination, for once to be free of responsibility, she revealed in it" (Makholwa, 2013:107). From the above, during her sexual intercourses, Tallulah gives up her authoritative trait to be handled in bed like a woman. By doing so, she fully enjoys her sexual intercourses there by making her attain sexualfulfilment as far as her sexual life is concerned.

Additionally, another instance where women possess sexual power is revealed through Janine. Her life as a stripper, a prostitute and a paralegal exposes Janine's liberal sexual life and the power she possesses. Alex Delaware employs her as a secretary to boom his dying law firm. Janine's sexual power here is revealed as she is able to revive Delaware's law firm. Though she is exploited for financial gains, the indispensability of Janine's sexuality is revealed thus depicting the power her sexuality has in the revival of Delaware's firm as it is portrayed in the following lines. 
she had been working for six years, and in that time, aside from sleeping with him intermittently, she managed to study and train as a real paralegal and had also managed to study and train as a real paralegal and had also managed to triple the number of clients in Alex's pathetic little one-man outfit or law firm as he called it. He always bragged that it was a strategic move on his side to hire her in the first place. (Makholwa, 2013: 8)

From the above instance, though Janine might be perceived as a prostitute, the power of her sexuality has led to the salvation of Alex's law firm. The salvation of his law firm by Janine reveals Janine's sexual prowess. This is duly because the more the clients she sleeps with, the higher the gains of Alex's law firm. As a result, apart from being Janine's clients, they automatically become the clients of Alex Delaware. Also, her liberal sexual life makes her to live a self-fulfilled existence as a woman. The sexual independence Janine enjoys no more makes her a victim in the hands of patriarchy as she lives according her own code of life. She does not depend on gender roles prescribed by patriarchy which often censors what a woman should do and what not to do behaviourally. Moreover, her job as a paralegal also helps her to amass enough money to further her studies in law. Through the power of her sexuality, Janine is able to attain whatever she wants in life and be wherever she desires to.

Also, Janine's sexual life as a prostitute makes her succeed in belonging to the South Africa's high class society. Through her introduction to Max Cameron by Delaware, she is able to get a pass to the class of elites in South Africa. Delaware's introduction of Janine to Max is revealed in the following lines, "Janine finally agreed to meet Max Cameron for a dinner that had been casually arranged by Alex... Max Cameron was a multi-millionaire widower who had been single for almost five years" (Makholwa, 2013:10). From the above lines, Alex does not only introduce Janine to rich men for her own benefit, but he also does this because he knows he will gain from Janine's relations with men. Delaware can be perceived here as a worthless man who relies on a woman's sexuality to make himself a name in society. Janine's sexual power does not only change Alex's life but also her own life as she is able to have a flamboyant lifestyle through Max Cameron. Furthermore, Janine's sexual power is exposed when Alex threatens to blackmail her when she changes her mind on their deal to kill Max and be bequeathed all his riches. From Alex's threats, Janine's sexual promiscuous life is revealed as the narrator indicates:

You and me are 50/50 partners in this scheme all the way. Don't think I've forgotten that all you were was a two-rand whore and don't ever think I'd hesitate to use that information against you anytime you start to piss me off. So you better be a good little whore and spread your legs for a fucking couple million...and like a good pimp I will make sure this operation goes nice and smooth. And listen', he said, pointing his finger at her', don't forget I still have those pictures from back '99-the ones with you and those two rugby players fucking the bloody life out of you! I don't think that's the kind of image befitting a millionaire's wife. (Makholwa, 2013: 69-79)

From the passage, Janine's sexual power is further revealed as she no more agrees on the deal her and Alex earlier decided. As well, Alex knows that it is only through her sexual prowessthat he can get Cameron's money; he threatens to blackmail her by exposing her promiscuous sexual life. The exposure of her love making scene with the two rugby players goes further to expose Janine's sexual power. Despite the fact that such an active sexual life is prohibited by patriarchy on women, Janine does not abide to such constraints, and lives an active sexual life which does not only make her live independently but equally makes her attain a certain social status through her sexuality. Janine here can also be compared to Ewudu in SoneDipoko`s Because of Women where Ewudu lives a sexually free life and does not want to be attached to any man as she has many amorous relations with many of the village men before being entrusted to a husband. Also, her body is perceived by many of the village men as a sexually gratifying body. Thus, her refusal to be attached to one man makes her to be perceived as a prostitute in her society. Though she is perceived as a prostitute she is an allegorical representation of those women who believe patriarchal culture is now archaic and defies it as a postmodernist or a social deviant. Although Janine views prostitution as a sort of sexual freedom, Shelia Jeffries(1997) in her book takes a different stand. In this work, she argues that prostitution is the ultimate act that instead reduces the woman to sexual objects that can be bought and sold in the market of sexual slavery, she posits: 
(Prostitution is) male sexual behavior characterized by three elements variously combined: barter, promiscuity and emotional indifference. Any man is a prostitution abuser who, for the purpose of his sexual satisfaction, habitually or intermittently reduces another human being into a sexual object by the use of money or other mercenary consideration. (Jeffries, 1997:4)

From the above quotation, Jeffries views prostitution as violence against the human liberty of women. Violence not only in the practice of prostitution but more fundamentally, in the very idea of 'buying sex' which is considered so inextricably linked to the absolute embodiment of patriarchal male privilege that lies at the foundation of women's oppression. Gail Pateson [1983] shares this opinion as he believes prostitution "...remains morally undesirable because it is one of those most graphic examples of men's domination over the woman" (56).

Besides, women further exercise sexual power through Nohmle, Thami's cousin. Nohmle snatches away Lloyd, Thami's husband from her. Despite the fact that it is because of her promising political affiliations that Lloyd marries her, Nohmle's sexual power is also exposed and her abnormal character revealed as she goes against moral ethics by seizing her cousin's husband. From Nohmle's character, some of the women in the text are ready to undertake anything even if it is at the risk of their lives or against moral ethics. Some transgress all conventions and morality in order to attain their endervours. From the behaviours of the above mentioned women, they can be defined by patriarchy as "Sex radicals" because they are women that do not abide to the definition of a woman by patriarchy. Thus, their behaviour coincides with radical feminist goals because its main aim is to defy patriarchy and the subversion of patriarchy is done by these women through their sexual acts of taboo. Though their acts are considered as offensive, it is one of the only ways through which these women live an expected fulfilled existence. In Makholwa's Black Widow Society, the women might not think they are defying patriarchy because the only thing they search for through these acts of taboo is their own happiness. Unfortunately, patriarchy might perceive their behaviours as an insult to the code of ethics that women ought to follow and respect in the society. Sarah Hoagland [1995] greatly lambasts hetero sexualism as she opines:

Hetero sexualism has certain similarities to colonialism, particularly in its maintenance through force when paternalism is rejected (that is, the stepping up of male predation when the women reject male protection) and in its portrayal of domination as natural (men are to dominate women as naturally as colonisers are to dominate the colonised, and without any sense of themselves as opposing those they dominate except during times of overt aggression) and in de-skilling of women. And just as colonisers who cannot survive as colonisers without the colonised, so it is the men who cannot survive as men (protectors and predators). (Hoagland, 1995:178)

Based on such an outlook, Thami possesses the conviction that it is right for her to eliminate Lloyd because it's through her efforts that he has become successful in politics. Lloyd thus acted as a protector when he needed her help, once he achieved his ambitions he is now acting like a predator by requesting for divorce. This malevolent act by Lloyd later leads to his assassination orchestrated by Thami. A similar situation is exposed in BuchiEmecheta's Second Class Citizen where Adah flirts with the Doctor who has to confirm her pregnancy. Though this attitude is prohibited in the Ibo society, Adah does this in order to be employed as a Librarian. As a woman and black in a racist English society, she indulges herself in an act of taboo to be able to survive. Thus, bad girls are used, discarded because they don't deserve better and they are not better enough to bear a man's children (Tyson, 2006:90). Though these women are termed as 'bad girls' by patriarchy, their attitude, goes in line with radical feminist goals which is that of defying patriarchy and all its norms. The sexual behaviour adopted by these women does not only make them to defy patriarchy but equally to change the status quo and transform the societal order. Thami and Adah's behaviours fall in line with black radical feminist concerns where black women interrogate why they are judged by the colour of their skin but not by the content of their character.

\section{Sexual Politics of The New Right}

Women as history records had greatly involved themselves in the political history of their nations. The engagement of women in these political struggles had been an acclaiming success because their presence had been left unnoticed. TalcotSparsons [1969] argues that "political power has to do with 
the capacity of persons or collectivities to get things done effectively, in particular when their goals are obstructed by some kind of human resistance or opposition" (232). Thus, when women empower themselves politically, they break the traditional notions that are attached to femininity. Engaging in political activities does not only make them stronger before the men who dominate the political field but is also to create a space of their own. Women through their dynamic political activities have greatly participated in the political histories of their nations. Through their dynamism, the women have left no stone unturned. The above analysis coincide with Kathleen Newland [1979] that

An examination of some other revolutionary regimes reveals a mixed record of achievements in the field of politics. Women have been active participants in the struggles of all modern national liberation movements. Women made the Long March in China; they joined in Mozambique's FRELIMO, in Algeria's FLN, and in the Russian Revolution from its earliest beginnings, and in the militant nationalist movements of dozens of now-independent nations. (Newland, 1979:111)

From the above, one can claim that women's involvement in the political life and in the national struggle has not let many of the now independent nations indifferent. Thus, women's participation in the political life of their nations has been accompanied with a lot of success. This success in politics due to women's involvement is the case of Makholwa's text. In South Africa, the massive participation of women in politics has massively been felt. The feminist scholar Gay Seidman [1989] asserts that women played a dynamic role in the liberation movement and that 7500 women fought during the conflict (232). This report on women's participation reflects the immense contribution of women in politics. Women's political participation is also revealed in Makholwa's text respectively.

Furthermore, in Makholwa's Black Widow Society we are presented to another politically active woman. As a politician and woman, she demarcates herself from all the women of her generation through her political activism. Though the offspring of tough politicians, she makes her own way in the field of politics without relying on her family's credentials to succeed in that field. Nohmle's dynamism as a cub politician is recounted:

She made her way up the party structures and was well positioned to be a key player in the newly formed ANC government. By 1994, when the ANC finally came to power, she was one of the young people who were poised to play a key role in the ANC YOUTH League. She immediately established a relationship with some of the high-ranking cadres in the party, and was greatly appreciated for her sharp mind and intellect...in her twenties, she was given the role of Chief Director at the Department of Education. (Makholwa, 2013: 43)

From the above instance, we realize that Nohmle is very dynamic as far as politics is concerned. This is because she successfully paves her way in the world of politics in South Africa. Her dynamism is seen with the confidence the government has on her by offering her a post of responsibility which she perfectly handles. Her political abilities at a certain point make Lloyd her brother-in-law to have a relationship with her as he dumps her cousin Thami. One can claim that the relationship that Lloyd knots with Nohmle to Thami's detriment is surely partly because he appreciates her successful political life and the power she demonstrates before the other women. Nohmle contrastively to Thami is a political activist and very dynamic woman while Thami is more mundane because she is attracted to material things. Also the fact they work in the same domain make Lloyd to appreciate Nohmle and her competence in politics. Besides, Nohmle's political dynamism greatly contradicts with the wide believe that women are not socialized to be comfortable with power, and that women lack the same driving ambition to acquire top posts of responsibility as men and that they are in low positions because of their natural inferiority (Nana-Fabu, 2007:25). The above statement contradicts with Nohmle's experiences because though her family's credentials are important, she succeeds in climbing the political ladder. Due to her professional competence, she is able to lead the Youth League of the ANC which is one of the most influential league of the most important branches of the party. Additionally, Nohmle's political dynamism has helped transcend the clichéd believe which the society has on some women.

In addition, a similar situation of a political activist woman is revealed in Ola Rotimi's Our Husband Has Gone Mad Again where Sikira one of Leoka-Brown wife's decides to create a political party. Sikira's aim of creating a political party is to fully represent women. The political party she wants to 
create symbolizes Sikira's freedom from a polygamous marriage where she has no voice and from a nagging husband who constantly oppresses her psychologically. Therefore having access to an important political post will imply that she will first of all change the situation of Women from the top before giving them a voice in the different households. From this instance, she also implies the politics of a country greatly oppress the woman and if women get in control of the country's politics, their situation will change. The above analysis greatly ties with Kathleen Newland's [1979] assumption where she declares that:

The law that has the greatest impact on women's daily lives is the civil law, specifically marriage and family laws. Whether customary or codify; it is civil law that sets the conditions for when and how a woman may marry, how and if her marriage may be dissolved, how far her authority over her children extends, what she can inherit if widowed, what support she is entitled to if divorced...Civil law in modern states is not single, monolithic entity. Its components are legislation, constitutions, statutes, court decisions, executive decrees and administrative regulations. (10)

From the above, we realise that it is the politics of a country that increases women's suffering apart from being oppressed by their husbands; the law comes in to reinforce their oppression through the sometimes partial law instituted in many countries. For instance, men are supposed to have more than one wife while women should not. From the above analysis, the keenness of Sikira is exposed here because she wants to head a party and once she is Prime Minister, and in position of power, she will amend all the unjust laws that are instituted against the women in the society. Politics is one of the domains through which women get access to power. The women in this text exhibit a lot of dynamism in their political activities. The political participation of these women also puts to question the notions of femininity like fragility, weakness and emotionality that is attached to women. The political involvement of these women reveals how successful and competent women can be in the different spheres of life. Thus, the political activism of women in the politics of their country greatly changes the destiny of their countries.

To begin, Tallulah, the head of the black widow society creates the sect with the aim of empowering women that are oppressed by their husbands. This empowerment is done through the elimination of their husbands. As a dynamic woman, many women, adhere to this sect to free themselves from bondage. From the onset Tallulah is constantly physically and psychologically oppressed by her husband. Tallulah's abuse by her husband is what leads her to create such a sect which will not only lead to her liberation but to that of other women. Tallulah's marriage can be compared to hell because her husband constantly abuses her physically and psychologically thereby making her live an unhappy marriage life. Tallulah's physical and emotional oppression is revealed thus:

He used to call her his child bride, and treated her like a precious germ...until he paid her lobola and set her up in her dream house. The first year of their marriage was blissful; exactly as she imagined life with MphikeleliNtuli would be. Then she fell pregnant with their first child, everything changed. It had started out as taunts about her physical appearance; then the cheating began and, with it, the beatings ensued. Her marriage is an albatross which tightens its noose around her neck with each passing year. (Makholwa, 2013:2)

From the above citation, Tallulah's marriage has been transformed from a bed of roses to a nightmare. The happiness she experiences in the early years of her marriage suddenly vanishes making her the voiceless in her marital home. Due to repetitive abuses, she decides to take away her husband's life. The killing of her husband is very symbolical because it is only after his death that she experiences freedom and selfhood. One can claim that these women are high profile criminals because though they give themselves a reason by claiming to stop the oppression they go through in their relationships, some of these women also kill for materialistic tendencies as most of the women are bequeathed their husbands properties. Also when they believe they will not really gain financially from the murder of a husband, they prefer not to engage in a non-profiting case. They kill because these men obstruct them from living a happy and fulfilled existence as far as their sexual economic and social freedom and happiness is concerned. Thus, they find themselves obliged to kill them because they cannot forever live with all the constraints that their partners put on their way. Besides, Edna Whitehead also finds herself with the obligation of killing her husband because of what she 
endures while married to him. She does not only suffer from emotional abuse but also from financial exploitation as she owns only twenty percent of the business estate she built together with her husband. Edna's financial and psychological abuse by her husband is revealed in the following lines

The ever calculating Jake had urged Edna to dilute some of her shareholding by bringing in a black woman with strong business credentials so that his firm will have BEE representation. Edna resisted the idea, as she already owned only 20 twenty percent of the company, she finally conceded as Jake was the dominant force in their relationship. Little did she know that by allowing Tallulah into their lives, she had only agreed to a clever business decision but that the alliance would serve her in her personal life. Edna told Tallulah of the humiliating 'cookie jar' that had been a feature of her marriage since her husband's vocal disappointment at her inability to bear him a heir...The cookie jar was a troop of sexually available secretaries who had been a constant in her more than two decade marriage. (Makholwa, 2013:39)

From the above passage, Edna throughout her marital life is abused financially and emotionally by her husband as everything is imposed on her by the latter. This situation might have also lasted forever if she did not sought ways to eliminate him. Edna seems to suffer a lot from this marriage seen with the way she is about to commit suicide. According to her, she believes committing suicide will clear off her problems. Edna's tragic end is avoided by Tallulah who brings back her feet on the ground. Through the Black widow society, she finds her space as a woman, and finally enjoys an emotional stability. She also gets the sole access of the business empire she built with her husband, which almost belonged to him alone. If Edna through Tallulah's help did not react radically against Jake Whitehead, Edna's life would have been miserable because her oppressive husband's attitude will not have ended. Due to this marital turmoil she is about to take away her life. Consequently, the elimination of her husband is a way to revive her and to enjoy a peaceful emotional life which was unattainable before. Jake is therefore a thorn in Edna's flesh which she has to get rid of. Thus, she orchestrates his death with no hesitation.

Furthermore, in Makholwa's text we are further presented to Salome who is married to Scott O'leary an Irish Casanova. Scott O'leary does not only tour around the world abandoning Salome to herself but he also infects her with HIV which he vehemently denies. The O'leary's situation greatly coincides with the South African reality as far as their sexual lives are concerned. Pettifor, Measham and Nancy Padian in their article titled "Sexual Power and HIV Risk in South Africa" assume that gender inequalities play a key role in the HIV pandemic through their effects on sexual relationships. In South Africa, multiple relationships are condoned and even encouraged for men while women are expected to be monogamous and unquestioning towards their partner's behaviour. Here, we better understand why Scott multiplies his sexual partners without adhering to his wife's advice also, due to his multiple sexual partners, he easily contracts HIV AIDS. Moreover, his bankruptcy is due to his flirtatious life style. Salome here finds herself in a dilemma as she is not only pregnant with his child but also infected with HIV and abandoned by her husband. The impasse in which she finds herself almost leads her to depression. Salome's desperate situation is revealed in the narrator's voice.

Scott had told her in no uncertain terms that she was not to share this news with anyone because all this talk about the disease was a mere figment of her imagination. He instructed her to terminate the baby because they already had enough with their two offspring. She knew that based on the prenuptial agreement she had agreed to sign during the heady days of her romance, she was not entitled to inherit any of his wealth. However, the truth gnawed at her on daily basis. She was beginning to behave erratically and feared she would plummet into depression. How could one live with such unbearable secret? When the strain tore at her, she finally confided in one of her clients at the beauty salon. (Makholwa, 2013: 50)

Salome thus finds herself in a dead end, the joining of the black widow society seem to be her only solution. Through the help of Khumalo, she joins the sect which relieves her of her pain and guarantees her future and that of her children. The society after the killing, assures the life of the widow and her children financially. Salome through the murder of her husband is portrayed as somebody who has not killed for pleasure but who has done it to relieve her pain and assuring her future and that of her children, given what Scott's death will bring to them financially. Thus, Scott is therefore a thorn in Salome's flesh which could prevent her to live happily, after the turmoil she had 
gone, through her unsuccessful marriage. Thus, Women in the text do not kill their husbands out of convenience, they kill them to be able to gain their own space and voice which have long been obstructed by patriarchy. By killing their husbands, they are able to have a satisfied existence.

As a result, women have to be politically active in order to be more independent because the politics of a society or a country is what also ties women down at the mercy of the men and the society at large. Apart from the society that oppresses her, the society in synergy with the men contributes to the oppression of some women. The politics of a country to a great extent helps in the oppression of some women. To topple some of the injustices felt by women in the society, the women have to be politically active in order to modify the discriminatory laws against women.

\section{DEVELOPING FEMINIST MATERIALISM}

Makholwa's Black Widow Society, is a depiction of economically reliable women who do not rely on their husbands efforts to make themselves a name in the field of business. The economic activities they undertake do not only make them independent financially, but, it also leads to the economic welfare of their respective families. Economic power is defined as having sufficient productive resources at command that give the capacity to make and enforce economic decisions such as allocation of resources and apportioning of goods and services (Business Dictionary.Com). The economic power these women enjoy helps them to attain create their own space. Some of the women who succeed economically are Tallulah, Salome, Edna Whitehead, and amongst others. By indulging in economic activities, the women are no more dependent on the man, but equally change their destinies. In most cases, the counterparts of these oppressed women believe the destinies of their wives depend on them. In order for us to better understand this section, our attention turns to Katharine Bartlett's [1987] where she states:

Men have power over everything of value in society, even the power to decide what has value and what does not. Men use this power systematically to shape and define the social beings we call men and women in ways which enhance the power of men, and keep women subordinate to men. How men have constructed the relationship between the men and women in turn shapes and constructs society as a whole such that each of its constitutive parts-its laws, its institutions, the private relationships it fosters-is hierarchically, by sex. Women, in short, have been and will continue to be in every sense until we understand our trap, seize the power to control our own lives and get men's feet "off our necks". (Bartlett, 1987:1560)

Bartlett thus rejects the prevailing legal strategies for improving the inferior position in which women find themselves. She finds the "equal treatment" approach of liberal feminists, which minimises differences between a man and woman as a basis for demanding equal treatment, but prefers the "dismantling of the status quo" approach by radical feminists, which highlights the female standards and values from which difference is measured and respected.

In Makholwa's Black Widow Society, Tallulah is said to be a successful business woman due to her success in the business field. As a result, she is not only admired, but also wants to be emulated by people who surround her. One of her admirers is the prominent attorney of the women's association who has succeeded to climb the judiciary ladder through the support given to her by the society. Definitely, she is one of Tallulah's admirers because Tallulah is one of those who give her a chance as far as her profession is concerned. Khumalo's admiration for Tallulah is revealed in the following narrator's voice: "She and Tallulah grew up together in the same Township in the East Rand...They were neighbours who were not particularly close due to their age difference but Tallulah became a role model to those who grew up with her when she made a name for herself in the business world" (38). This reveals how Tallulah's success does not only benefit her but also, she is a source of inspiration to young women in her community. Tallulah's economic independence makes her not rely on her husband financially but also to help out young women to get on with their lives. As someone who inspires women, and a militant of the economic independence of women, she employs Khumalo as the attorney of the society because she sees her as a hard working lady. Consequently, as a radical feminist, she does not only inspire them, but also employs them if necessary. The economic power that Tallulah enjoys boosts the young women around her to work harder and be successful in business like her. Her success is depicted when she makes a lot of profit during the world cup in South Africa. Her successful business exploit is revealed thus: 
Years ago after she started expanding her business interests following Mphikeleli's death, a friend of hers had sold her a promotions company that produces marketing materials for sporting and corporate events. Ever the shrewd businesswoman, Tallulah had acquired a FIFA license to brand car decals during the World Cup and her promotions company had never enjoyed such high profit margins over a short period. She often heard people bemoan the fact that the World Cup had not been profitable for their business but what did they expect. (Makholwa, 2013:104-106)

This excerpt is a succinct proof that Tallulah's successful business life portrays her as an astute business woman. Because, she knows what to sell at a given season in order to make high profits; she does not produce and sell her products carelessly. Furthermore, Tallulah sets up a secret cult that is The Black Widow Society which is apparently an association which disentangles women from men's bondage but keenly looking at the association, it is a profit making association. Though the primary objective is to free women from marital bondage, the aim of the association is also to make sure the widows after killing their husbands will face no major financial problem so the husband's money is bequeathed to the widow. From Tallulah's firm and her parallel economic activities in the Black Widow society, she spurs her economic success thereby making her a role model in her society and an example worth emulating. The lack of financial reward concerning the China Gumede's case greatly exposes the profit making nature of their association as they are disturbed with the fiasco with which the murder of China is conducted. Despite this fiasco, they are quickly relieved of its failures as Salome's case presents itself and from which they wish they will reap a lot of benefits. Also, Tallulah's success as a business woman is also exposed through her residence. She leaves in a luxurious neighborhood and the description of her house leaves the reader with the impression that she is a millionaire. Tallulah's prestigious life is envisage as the narrator says: "Tallulah's house in Hyde Park...Tastefully furnished in fine antiques, crystal land white drapes, Persian rugs and an eclectic collection of modern and classic art pieces, Tallulah's home embodied perfection and bore testimony of her impeccable taste" (35). This exposes Tallulah as a financially wealthy woman as the description of her house leaves us with no doubt of her wealth. From the butler who manages her house to the eighteenth year, the whisky she drinks and the cigar she often smokes depict her as a 'black diamond' in the South African society. Apparently, she is a woman who lacks nothing and is fully accomplished as a business woman.

In addition Edna Whitehead one of the members of the triumvirate after her husband's death also enjoys economic power. Before her husband's death, she is a shadow of the latter as she is simply the house keeper because of her meaningless nature in his economic and emotional life. Her meaninglessness in Jake Whitehead's life goes from the number of secretaries who are his mistresses and the insignificant twenty percent shares she has in the family estate. All this makes her a mere shadow in her husband's life. With the death of her husband, Edna metamorphoses into an emotionally strong and wealthier woman because the family's property is bequeath to her all alone due to the absence of a legitimate child. Edna's rise to economic welfare through sisterhood is exhibited by Tallulah and the association at large. Tallulah's supporting attitude towards Edna is revealed in the following lines. "They not only managed to eliminate Jake Whitehead forever, but they also birthed an emotionally stronger and considerably wealthier Edna Whitehead. When Jake Whiteheads' insurance paid out and the estate wound up, all parties were reimbursed for their contribution" (40). Thus, the solidarity that exists between Edna and the members of the society brings Edna's feet back to the ground. Though Edna has become emotionally and financially strong because of the black widow society, she is not the only one who has profited from her husband's death because the society at large too has profited from Jake's murder. Besides, the death of Jake is not only emotionally beneficial but equally financially advantageous to Tallulah, Khumalo and Mhzwake as they will have their share of Jakes' estate. From the above, we realize that in most cases, these women get access to economic welfare through uncouth ways like murder. Tallulah and the members of the triumvirate have made the death of their husbands a business wherein the more they have nagging husbands, the more they witness an increase in their business and an increase in the profits of the association.

From another perspective, the economic welfare of the women in Makholwa's text is portrayed through Khumalo the attorney of the secret cult. As the attorney of the black widow society, she is 
more concerned with the fiscal and financial matters of the association. Thus, she has to make sure that the secret cult makes much profit as the number of murdered husbands increase. The role played by Khumalo in the association is defined and precised in the following lines "Nkosazana's focus tended to be more on fiscal matters; how much the BWS made and how much more potential it had become a highly profitable organization" (38). From the above lines, Khumalo has to make sure the association is to be highly profitable despite its philanthropic goals. She is so well off that her old time friend that is Alex who earlier helped her in the past wishes to know where her wealth as an attorney comes from. Despite the fact that he is Nkosazana's mentor, he has never succeeded to be up to his former protégé's level. Alex's puzzled nature over Khumalo's wealth is revealed in the following narrator's voice.

They'd kept in contact over the years with sporadic encounters conducted mostly over the phone. The few times they managed to meet, she was always decked out in the latest designer gear...And the cars! My word, this woman seemed to be upgraded her cars with every new model on the market! What got Alex's goat was how in the world an NGO could afford to finance such a lofty existence? These black people sure knew how to cream a scheme, that's for sure. (Makholwa, 2013:115)

From the above excerpt, Nkosazana lives a very luxurious life; the brand of cars she uses is a clear depiction that she is financially viable. The wealthy nature she reveals makes Alex to seek for her help as he is in a financial mess as far as his life is concerned. Though an old attorney, he has not succeeded to live the type of life Nkosazana lives or make much money as she has made from her profession as an attorney. Also, Khumalo further reveals the lucrative aspect of the association due to her refusal to handle Salome's case because she believes it will not bring them a lot of profit. This instance reveals Khumalo's main aim which is that of making profit and upgrading her life style instead of helping out the desperate women faced with abusive husbands. Khumalo's materialistic actions are revealed when she complains about Scott's bankruptcy due to his philandering life style. Scott's situation is expressed in the subsequent lines:

Nkosazana picked up her briefcase and took out a blue arch-lever file containing a batch of documents. These are his financials... or at least what I could gather from Salome. Look at his list of assets then counter that against his liabilities...the man's estate is in shambles. With his playboy lifestyle, who knows what wealth he has left, if any. At first I was quite excited by the prospect of adopting Salome's case, especially after the China Gumede debacle but on closer inspection, things look a bit thin in foreign banks. Not sure if this case is worth taking up. (Makholwa, 2013: 52)

From the passage above, Nkosazana is exposed as a very professional lawyer. Since she is concerned with the financial and fiscal matters, she perfectly knows which case will bring them a lot of money and which case will not. Consequently, she warns the members of the triumvirate of a non-profit making case. Therefore, the dexterity with which she handles the different cases they are faced with and her professionalism unavoidably makes her an economically well-to-do woman. Thus, we realize that Nkosazana is very money-minded and less concerned with the problems faced by the women because she is a lesbian and has never had an experience of an emotionally, financially and physically abusive relationship. Her state as a lesbian makes her almost insensitive to the plight of the women.

\section{CONCLUSION}

Thus, the solidarity of the group does not only assure their physical and emotional happiness but also guarantees them of financial gains which some of them have been deprived of while married to their oppressive husbands. Furthermore, as far as Makholwa's narrative is concerned, the women also empower themselves through their silent voices. From the above analysis, we realize that South African women are very dynamic in all the activities they indulge themselves into. From the political, economic and social sphere, the women in this text demarcate themselves through the way they excel in their different endeavors. Besides, the power these women enjoy here is solely to attain create their own space. Thus, they indulge in the most dubious and radical means in order to attain their goals. They use unorthodox means to obtain what they desire. The radicalism and violence they use goes in line with Fanon`s assertion when he says "decolonization is a violent phenomenon" (Fanon, 1973:12). From the lives of these women, we realize that if they did not 
make use of violence, they would not have put an end to the master-slave relationship they have with the men. Additionally, some of the women here tend to put aside the morality the society imposes on them to get along with their lives. Some get on with their lives faithfully, while some do not only murder those who can impede on their way to freedom but also kill for money, and use their bodies to climb the social ladder.

\section{REFERENCES}

[1] Alice, E and Ellen W. (1990). Daring to Bed: Radical Feminism in America. NewYork: Routledge.

[2] Ashcroft, B et al. (1995). The Postcolonial Studies Reader. London: Routledge.

[3] Bartlett, K. (1987). "MacKinnon's Feminism: Power on Whose Terms'. California Law Review. 75.4. (pp.15591570).

[4] Cudjoe, S.R. (1980). Resistance and Carribean Literature. London: Routledge.

[5] Debeuvoir, S. (1949). The Second Sex. New York: Knopf.

[6] Dipoko, M. (1968). Because of Women. London: Heinemann.

[7] Emecheta, B. (1974). Second Class Citizen. Glasgow: William Collins and Co. Ltd.

[8] Fabu-Nana, S. (2007). The Feminization of Poverty in Cameroon. Yaounde: Editions Clé.

[9] Fanon, F. (1973). The Wretched of the Earth. London: Penguin Books Ltd.

[10] Hoagland, S. (1995). "Moral Revolution: From Antagonism to Cooperation" in Nancy Tuana and Rosemarie Tong (eds). Feminism and Philosophy: Essential Readings in Theory, Reinterpretation and Application. Colorado: Westview Press. (pp. 175-192).

[11] Kumar, M. (2013)."Postcolonial Feminism looking in to Within-Beyond to Difference". International Journal of English and Literature. 4.4: (pp: 129-143).

[12] Lovenduski, J. and Vicky R. (1993). Contemporary Feminist Politics: Women a Power in Britain. New York: Oxford University Press.

[13] Makholwa, A. (2013). Black Widow Society. Johannesburg: Pam Macmillan.

[14] Mary, D. (1978). Gyn/Ecology: The Metaethics of Radical Feminism. Boston: Beacon Press.

[15] Newland, K. (1979). The Sisterhood of Man: The Impact of Women`s Changing Roles on Social and Economic Life Around the World. New York: Norton and Company.

[16] Pettifor A, Measham D, Rees H, Padian N. (2004) " Sexual Power and HIV Risk in South Africa. Emerging Infectious Diseases". 10.11. (pp: 1-9).

[17] Pokol, B. (2010) "Forms of Judicial Power". Journal of Legal Theory. 4.34. (pp:309-320).

[18] Rotimi, O. (2006). Our Husband has Gone Mad Again. Ibandan: University Press

[19] Seidman, G. (1989). "Women in Zimbabwe: Post-Independence Struggles". Feminist Studies. 10.3. (pp: 419-440).

[20] Shelia, J. (1997). The Idea of Prostitution. London: Heinemann Press.

[21] Shulamith, F. (1970). The Dialectic of Sex: The case for Feminist Revolution. NewYork: BantamBooks.

[22] Sparsons,T. (1969)."The Concept of Political Power: Procceedings of the American Philosophical Society". 107. 3. (pp: 232).

[23] Tyson, L. (2006). Critical Theory Today: A User Friendly Guide.2ND.Ed. New York: Routledge.

Citation: Prosper A. NtamboNtambo, Pamela Christelle N. "Misogynism and the Dynamics of Power: A Radical Feminist Reading of Angela Makholwa's Black Widow Society". International Journal on Studies in English Language and Literature (IJSELL), vol 6, no. 1, 2018, pp. 28-39. doi:http://dx.doi.org/10.20431/23473134.0601005.

Copyright: (C) 2018 Authors. This is an open-access article distributed under the terms of the Creative Commons Attribution License, which permits unrestricted use, distribution, and reproduction in any medium, provided the original author and source are credited. 